\section{Aortic wall rupture from a mediastinal tumor invasion diagnosed by endoscopic ultrasound}

Rupture of the aorta from tumor infiltration is a rare event, described in only a few case reports to date $[1-4]$. It represents a life-threatening condition with the prognosis strongly dependent on its early recognition, which allows life-saving emergency interventional therapeutic procedures to be performed [5].

We present the case of a 57-year-old man with a posterior mediastinal mass who was referred for endoscopic ultrasoundguided fine-needle aspiration (EUS-FNA). During the procedure, a large parietal break in the posterior wall of the aorta was observed, which appeared to communicate with the inner part of the mediastinal tumor. The vascular nature of the tumor was confirmed by color Doppler examination ( Fig.1, Video 1). This finding had not been present on a thoracic computed tomography (CT) scan 2 weeks before the procedure.

The EUS-FNA procedure was aborted and another chest CT scan was immediately performed, confirming the aortic pseudoaneurysm formation due to tumor invasion. Aortography with placement of two endoprostheses was immediately carried out, with success. A repeat EUS 2 days later, with FNA of the tissue surrounding the now obliterated pseudoaneurysm ( $\bullet$ Fig. 2), was performed using a 25-gauge needle ( $\bullet$ Video 1 ), and a diagnosis of high degree spindle cell sarcoma was made.

Vascular structures represent important landmarks during EUS examinations. Thus, endosonographers can incidentally detect abnormalities of the aorta or any other big vessel, which in some cases might be mistaken for a lesion of a different nature [6-8]. In the presented case, the use of EUS made it possible to diagnose aortic pseudoaneurysm formation, which constituted a "ticking time bomb" in this patient, making it essential to abort the risky endoscopic procedure (EUSFNA), which could have become lethal [9]. The procedure was rescheduled only

\section{Video 1}

Case study of a 57-year-old man with mediastinal tumor invasion into the aorta.
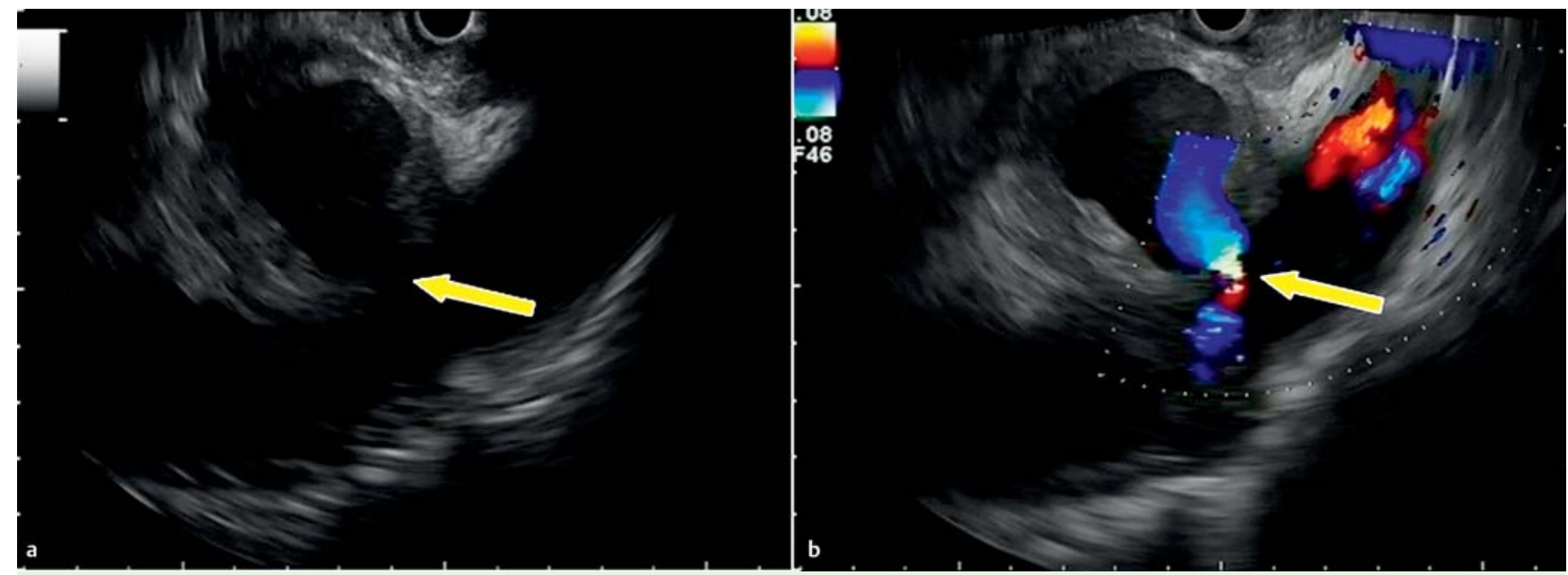

Fig. 1 Endoscopic ultrasound view of the aortic wall defect (arrows) communicating with the inner part of the tumor. a B-mode. b Color Doppler examination.
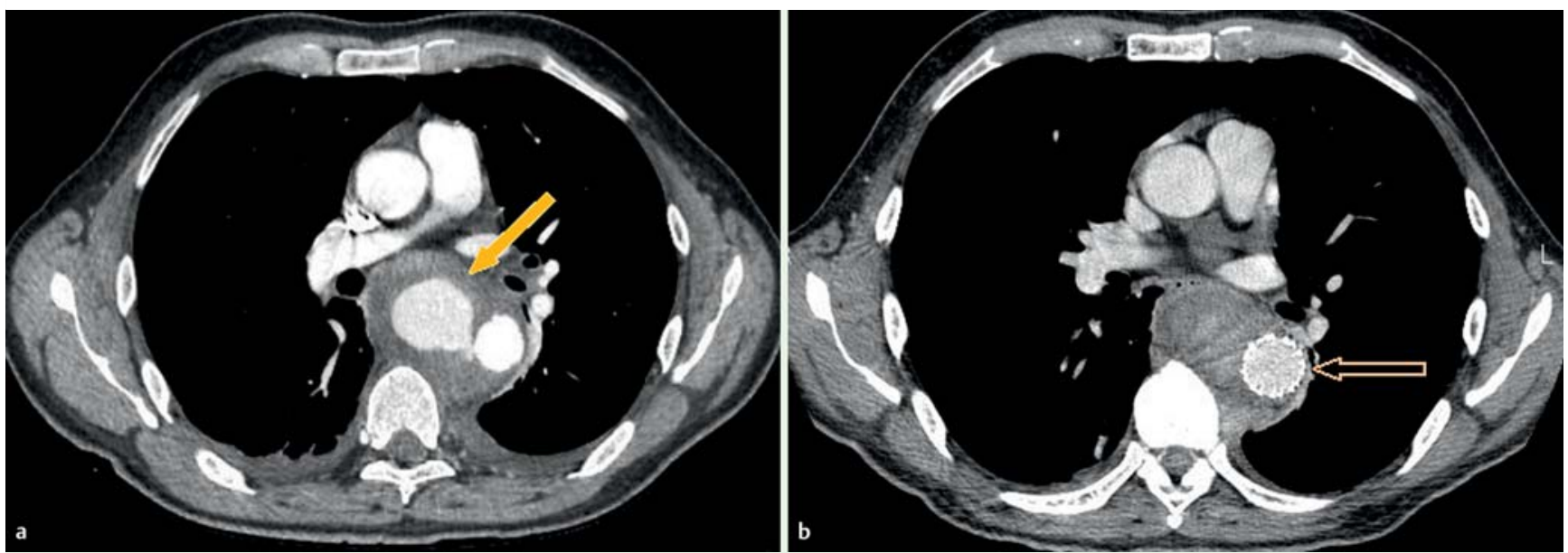

Fig. 2 Computed tomography of the chest showing pseudoaneurysm (yellow arrow) before and after endograft placement into the thoracic aorta (empty arrow). a Before endograft placement. b After endograft placement, which resulted in complete resolution of the pseudoaneurysm. 
after this procedural risk had been reduced, as saving a life is undoubtedly infinitely more important than a tissue diagnosis.

\section{Endoscopy_UCTN_Code_CCL_1AF_2AC}

Competing interests: Dr. Larghi is a consultant for Cook Medical and Boston Scientific, and has received research support from Olympus.

\section{Mihai Rimbaș ${ }^{1,2}$, Fabia Attili ${ }^{1}$, Alberto Larghi ${ }^{1}$}

${ }^{1}$ Digestive Endoscopy Unit, Catholic University, Rome, Italy

${ }^{2}$ Gastroenterology Department, Colentina Clinical Hospital, Bucharest, Romania

\section{References}

1 Tsuchida R, Kasahara $N$, Inobe $M$ et al. Aortic intramural hematoma associated with metastatic carcinoma. Pathol Res Pract 2010; 206: 839-845

2 Falcone JL, Go MR, Baril DT et al. Vascular wall invasion in neurofibromatosis-induced aortic rupture. Vasc Endovascular Surg 2010; 44: 52-55

3 Stambo G, Valentin M, Kerr TM et al. Endovascular treatment of an acutely ruptured abdominal aorta from tumor invasion by an unresectable retroperitoneal leiomyosarcoma. Ann Vasc Surg 2008; 22: 568 - 570

4 Cantwell CP, Stack J. Abdominal aortic invasion by leiomyosarcoma. Abdom Imaging 2006; 31: $120-122$

5 Collaud S, Waddell TK, Yasufuku K et al. Thoracic aortic endografting facilitates the resection of tumors infiltrating the aorta. J Thorac Cardiovasc Surg 2014; 147: 1178-1182

6 Muraki S, Inguu A, Baba M et al. [A case report of a pseudoaneurysm of the thoracic aorta (thrombotic closure type) showing like a mediastinal tumor - value of endoscopic ultrasonography in differential diagnosis]. Nihon Kyobu Geka Gakkai Zasshi 1996; 44: 1917-1920

7 Varadarajulu S, Eloubeidi MA. Diagnosis of an aneurysm masquerading as a pancreatic-cyst lesion at EUS. Gastrointest Endosc 2007; 65: 721 - 725
8 Nagamatsu H, Takahashi K, Ueo T et al. A case of splenic artery aneurysm simulating a pancreas tumor. Nihon Shokakibyo Gakkai Zasshi 2011; 108: 1420-1427

9 Lachter J. Fatal complications of endoscopic ultrasonography: a look at 18 cases. Endoscopy $2007 ; 39: 747-750$

\section{Bibliography}

DOI http://dx.doi.org/

10.1055/s-0034-1391243

Endoscopy 2015; 47: E66-E67

(c) Georg Thieme Verlag KG

Stuttgart · New York

ISSN 0013-726X

\section{Corresponding author}

\section{Alberto Larghi, MD, PhD}

Digestive Endoscopy Unit

Catholic University

Largo A. Gemelli 8

00168, Rome

Italy

Fax: +39-06-30156581

albertolarghi@yahoo.it 